\title{
An overview of subclinical mastitis in dairy cattle
}

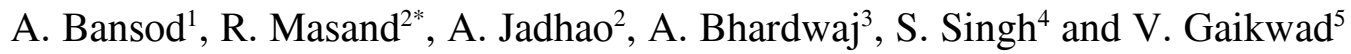 \\ ${ }^{1}$ Department of Animal Nutrition, Indian Veterinary Research Institute, Izatnagar-243 122, Bareilly, \\ Uttar Pradesh, India; ${ }^{2}$ Department of Veterinary Pathology, Guru Angad Dev Veterinary and Animal \\ Sciences University, Ludhiana- 141 004, Punjab, India; ${ }^{3}$ Department of Gynecology and Obstetrics, \\ Guru Angad Dev Veterinary and Animal Sciences University, Ludhiana- 141 004, Punjab, India; \\ ${ }^{4}$ Department of Veterinary Microbiology, Guru Angad Dev Veterinary and Animal Sciences University, \\ Ludhiana- 141 004, Punjab, India; ${ }^{5}$ Department of Animal Nutrition, Guru Angad Dev Veterinary \\ and Animal Sciences University, Ludhiana- 141 004, Punjab, India
}

\begin{abstract}
This manuscript describes economic losses, prevalence, etiology, nutritional approaches, risk factors, diagnostic tests, and control to preclude the causes of subclinical mastitis in dairy cattle. Subclinical mastitis is more disparaging than clinical mastitis. It is almost asymptomatic, with no visible changes observed on the udder; only milk production reduces and milk quality changes. It is a multi-etiological complex that includes nutritional deficiency, number of lactations and unhygienic managemental practices. Diagnosis of subclinical mastitis is quite difficult than clinical mastitis. The detection of subclinical mastitis in suspected quarters can be made using either direct measurement of the somatic cell count (SCC) or indirectly by performing a California Mastitis Test (CMT). Intramammary antibiotics are widely used to treat cows infected with Streptococcus agalactiae and have a positive response in production and decrease bulk tank SCC as well. Penethamate is efficacious and sustains a positive effect to reduce SCC in milk against subclinical mastitis.
\end{abstract}

Key words: Asymptomatic, CMT, Economic loss, Intramammary antibiotics, Subclinical mastitis

\section{Introduction}

Livestock productions play a major role in the economy of the country and the life of human beings. Mastitis, in particular, subclinical mastitis is a very common disease that occurs in dairy cows and causes more significant economic loss due to its prolonged effect throughout the lactation period. The term 'mastitis' originated from the Greek word Mastos or Mammae meaning breast and itis meaning inflammation. Radostits et al. (2007) defined mastitis as an infection or inflammation of the parenchyma of the mammary gland. Drug residues in milk enable easy transmission of the organism to the human population and also create public health issues and economical threats (Kader et al., 2002).

Mastitis is inflammation of the parenchyma of mammary glands characterized by bacteriological changes in milk, milk production and pathological alteration in glandular tissues. It is one of the leading diseases of dairy cattle that potentially affect farmers' economy due to reduction in milk yield, milk discard after treatment, cost of treatment, and premature culling. Mastitis is categorized as clinical and subclinical mastitis based on signs and changes in milk quality and quantity of affected cows. The main features of clinical mastitis are edema, udder inflammation with constant and steady pain, and change in colour and consistency of milk, whereas only quality and quantity are reduced with no visible changes in udder observed in subclinical mastitis which make them complex in detection. So, diagnosis of subclinical mastitis (SCM) is difficult than clinical mastitis. When a cow is in heat, or there is a climate change, subclinical mastitis is converted into clinical mastitis (Saroj et al., 2015). On the other hand, many microorganisms are implicated in mastitis infection, few of them are environmental

"Corresponding Author, E mail: r.masand93@gmail.com 
pathogens, and some are contagious (Ruegg, 2017).

The milk from affected quarters seems to be normal, even when millions of somatic cells (SC) present in milk, and hence SCM can also be defined as when milk is normal but there may be a decrease in production and may have SCC level of 200,000 cells $/ \mathrm{mL}$ or greater and can be detected through California Mastitis Test. Therefore, herd screening for SCM infection should be done regularly to prevent milk production loss (Halasa et al., 2009). In the current scenario, MALDI-TOF MS has been used in many countries to detect mastitis because of its speed and reliability (Nonnemann et al., 2019). Therapeutic and prevention strategies have been practiced over the years to improve the health and production of dairy animals which contributes to the economy of the country (Barkema et al., 2006; Pérez et al., 2009; Pereira, 2011; Keefe, 2012).

\section{Economic impacts of subclinical mastitis in dairy cow}

Subclinical mastitis has a negative influence on the performance of dairy cows and buffaloes. It has a significant impact on production, nearly $10-20 \%$ decrease in milk production, as it causes an undesirable effect on the milk constituents, which affects its nutritional value and renders it unfit for processing and consumption (Iraguha et al., 2015). It includes reduced milk production, changes in milk quality and treatment cost. Rathod et al. (2017) estimated the economic losses due to subclinical form of mastitis were approximately in the range of INR 21,677 to INR 88,340 per animal for a lactation period. It has been reported that SCM causes threefold more production losses as compared to clinical mastitis leading to substantial economic losses of $60-70 \%$ all due to mastitis (De Vliegher et al. 2012; Sinha et al. 2014).

Susanty et al. (2018) observed agro climatic effects on milk production and shows subclinical mastitis prevalence in dairy cattle.
Another study revealed that the prevalence rate of mastitis in cows was high as environmental temperature increases significantly (summer) due to the rise in somatic cell score (Bouraoui et al., 2002; Khate and Yadav, 2010; Bertocchi et al., 2014). The temperature and humidity index (THI) can regulate the comfort zone of cows. The incidence of clinical mastitis progresses with an increase in the temperaturehumidity index (THI). In addition, increase THI is related to mastitis prevalence and somatic cell score (Hammami et al., 2013). A rise in somatic cell count in dairy cattle linked with mastitis also reported by Barkema et al. (2013). Any variation of the body temperature above the normal range suggests the level of heat stress in dairy cattle and also affected by wind speed, dry temperature, humidity and solar radiation (Dikmen and Hansen, 2009). It has been observed that room temperature below $23^{\circ} \mathrm{C}$ and humidity of $68 \%$ is most suitable for the highest production of milk by dairy cattle (Bohmanova et al., 2007). Hence, temperature and humidity play a crucial role in the production of dairy cattle.

\section{Prevalence of subclinical mastitis}

Balaji and Senthilkumar (2017) reported a prevalence rate of $67.80 \%$ of subclinical mastitis in 80 dairy cows of the Theni district. The prevalence of subclinical mastitis in dairy cows varied from 15 to $75 \%$, whereas the involvement of quarters varied between 5 and $40 \%$ (Cynthia, 2005). Due to the importance of unseen nature and massive impact on health and production in lactating cows, gathering information about its prevalence across India provide a guideline for strategic management and control of the disease to reduce economic losses in the dairy sector. The states of Punjab, Haryana, Uttar Pradesh, Madhya Pradesh, and Maharashtra had estimates of $53.52 \%, 51.18 \%$, $39.58 \%, 62.49 \%$ and $35.11 \%$ subclinical mastitis respectively (Bangar et al., 2015). According to Busato et al. (2000), subclinical mastitis prevalence at the quarter level was $21.2 \%$ for a lactation period of 7 to 100 days 
and $34.5 \%$ for 101 to 305 days postpartum in organic certified dairy farms. According to Varshney and Naresh (2004), the prevalence of subclinical forms of mastitis was more common in India. It was $10-50 \%$ in cows when compared to clinical mastitis (1-10\%). Ghose and Sharda (2003) had depicted the prevalence rate of subclinical mastitis rate in dairy cows was $52.48 \%$.

Sharma et al. (2008) reported a high prevalence rate in dairy cows that was $78 \%$. Abrahmsén et al. (2014) observed $86.2 \%$ cases of subclinical mastitis through CMT screening of one or more quarters in dairy cows. Mpatswenumugabo et al. (2017) conducted a cross-sectional study in dairy farms of Rubavu and Nyabihu districts, Rwanda using the California Mastitis Test and found $50.4 \%$ prevalence rate of subclinical mastitis in dairy cows. Sumon et al. (2017) reported the subclinical prevalence rate in dairy cows was $25 \%$.Yadav et al. (2019) found a higher prevalence rate of subclinical mastitis in cows (38.33\%) as compared to buffaloes $(16.32 \%)$. Senthilkumar et al. (2020) depicted the subclinical mastitis prevalence rate based on the stage of lactation: early, mid and late stage of lactation, the prevalence of subclinical mastitis was $28.57 \%, 6.67 \%$ and $16.67 \%$ respectively. The quarter wise-right forequarter, right hindquarter, left forequarter and left hindquarter, the prevalence of subclinical mastitis was $16.66 \% ; 54.17 \% ; 8.33 \%$ and $20.83 \%$ respectively.

On the basis of parity, from first to fourth parity, the prevalence of subclinical mastitis was $9.09 \%, 16.66 \%, 25.00 \%$ and $25.00 \%$ respectively. The prevalence rate of subclinical mastitis based on cultural examination was quarter-wise $(64.21 \%)$ and cow wise (39.83\%) (Pankaj et al., 2012). Bangar et al. (2015) studied the prevalence of subclinical mastitis on cow-basis using 6344 cows from 25 farms and found to be $46.35 \%$ (95\% CI 39.38; 53.46). Meta-analysis for the quarter-wise prevalence of subclinical mastitis was carried out using 18,721 udder quarters of dairy cows from 23 studies, and the pooled estimate of the prevalence of subclinical mastitis on quarter-basis was found to be $23.25 \%$ (95\% CI 18.15 ; 29.27). Devi and Dutta (2018) reported the incidence rate of subclinical mastitis cow-wise and quarter-wise on the basis of Somatic Cell Count (SCC) as $93.33 \%$ and $90.26 \%$ respectively in organized and unorganized farms in and around Khanapara, Guwahati, Assam. Mbindyo et al. (2020) reported the overall prevalence of clinical and subclinical mastitis was $51.6 \%(815 / 1580)$, $74.4 \%(294 / 395)$ and $76.6 \%(118 / 154)$ at the quarter, cow and farm level, respectively. The prevalence rate of subclinical mastitis was observed high in European crossbreds than in local breeds (Abdeta and Gemechisa, 2020).

\section{Etiology of subclinical mastitis in dairy cattle}

The foremost causes of SCM in dairy animals are due to many factors such as unhygienic management, nutritional deficiency and several pathogens. Multiple causative factors are involved in SCM occurrence and its severity depend on various variables of the host, pathogens, and the environment. Cheng and Han (2020) stated that multiple pathogens that contribute to causing mastitis included contagious organisms, environmental bacteria and opportunistic bacteria. Other organisms such as fungi are less frequently a cause of mastitis in dairy cows. The bacterial etiology are Streptococcus agalactia and Staphylococcus aureus, Nocardia spp., Mycoplasma spp. and environmental Streptococci. Another report showed that Staphylococcus spp., Streptococcus spp., Micrococcus spp., Trueprella pyogenes, Corynebacterium bovis and Bacillus spp. were causing bovine mastitis in 82 lactating cows (Mollalegn et al., 2010). Hande et al. (2015) identified the bacterial isolates of Staphylococcus aureus, Streptococcus dysgalactiae, Enterococcus spp. and Streptococcus agalactiae from the cases of subclinical mastitis in dairy cattle in the Samsun district of Turkey. 
Host factors and environmental factors play an essential role in the occurrence of the disease in animals. A wide range of microorganisms can enter the mammary gland through the teat canal and cause disease. Sources of environmental exposure are unhygienic managemental conditions such as contaminated manure, bedding, feeds, dirt, mud and water. Fahim et al. (2019) observed that E. coli strains are causing intramammary infections including subclinical mastitis. Banerjee et al. (2017) observed that Pseudomonas aeruginosa is one of the etiological pathogens of subclinical mastitis in dairy cows. Karabasanavar et al. (2019) reported that Staphylococci were isolated and confirmed using $16 \mathrm{~S}$ rRNA genebased genus-specific PCR in $39.2 \%$ of SCM affected quarters and detected virulenceassociated nuc gene in $75 \%$ of Staphylococcus isolates suggesting their potential pathogenicity.

The high prevalence of subclinical mastitis was associated with different factors, including herd size, milk marketing, agro-climatic conditions of a region, animal owner education level, variations in sociocultural practices, feeding methods and management (Joshi and Gokhale, 2006). Ndahetuye et al. (2019) reported the non-aureus Staphylococci (40.2\%) most prevalent microbes of subclinical mastitis, followed by Staphylococcus aureus (22\%). Another study showed that Streptococcus species $(22.2 \%)$ were the most recorded pathogen for subclinical mastitis, followed by Staphylococcus aureus (15.7\%), Pseudomonas aeruginosa $(5.1 \%)$ and Enterobacter species (0.7\%) (Mbindyo et al., 2020). A study identified the causative agents of subclinical mastitis in dairy cows as Staphylococcus aureus, Streptococcus uberis, Streptococcus agalactiae, S. dysagalactiae and $S$. pyogenes, E. coli, Proteus spp. and Klebsiella pneumoniae by using PCR techniques (universal $16 \mathrm{~S}$ primers) (Sahoo et al., 2020).

Nutritional factors: The number of lactations, metabolic stress and protein-energy ratio may affect the immune system and induce the cause of mastitis in animals. Immunosuppression can be linked to metabolic disturbance and changes in the modulation of immune system, which may lead to mastitis and reduce milk production (Bronzo et al., 2020). Dey et al. (2019) stated that proper balance of nutrients prevents mastitis while nutritional imbalance or sudden change in diet may enhance mastitis incidence in the dairy cow.

Vitamin A and zinc play an essential role in maintaining the physical defense barriers as well as epithelial health of the udder. The functions of phagocytic cells in cattle are influenced by vitamins (A and E), copper, zinc and selenium. Nutritional supplementation of dairy cows with vitamin $E$ enhances the killing ability of immune cells (neutrophils). The nutrient imbalance may be occurring due to either excess or deficiency of essential nutrients in the diet of dairy animals (Haq et al., 2016).

Risk factors: The major risk factors of SCM include host, management practices, diet and pathogens. The host factor consists of age, stage of lactation, milking interval, breed, parity, milk yield capacity, udder and teat conformation, somatic cell count, udder defense, dry period, teat injuries and genetic resistance. Cows of certain breeds are more prone to mastitis. Among Swedish breeds, a high prevalence of mastitis has been recorded in Swedish Holstein cows. Crossbred cows are more susceptible to mastitis than local breeds (Persson et al., 2009). Managemental practices comprise shed and udder hygiene, poor teat condition, poor environmental hygiene, milking technique, sanitation and large herd size, use of handwash cloth, teat dipping and hygiene of milking machine.

\section{Diagnostic test for subclinical mastitis}

Microbiological status of the affected quarter and the somatic cell count (SCC) used to detect abnormal changes are mainly due to the inflammatory process (Sudhan and Sharma, 2010). Tresamol et al. (2019) found that EC estimation to be easier than CMT as a screening test. Langer et al. (2014) stated that many direct and indirect tests help to detect SCM. The direct 
test includes Somatic Cell Count, and the indirect test includes Modified California Mastitis Test (MCMT), Modified White Side Test (MWST), Cow Side Test, Screening Test [Electrical conductivity (EC) and $\mathrm{pH}$ test] and Laboratory Test [Methylene Blue Reduction Test (MBRT)]. These tests determine the quality of milk. However, in the absence of laboratory facilities, a suitable field-level test may be considered in detecting SCM (Sharma et al., 2008).

Inflammation of the mammary gland is directly accompanied by an increase of SCC in milk (Rodriguez et al., 2000). Therefore, SCC is a standard test for SCM (Durr et al., 2008) and represents a direct test for detecting SCM. Reddy et al. (2015) reported that the quarterwise incidence of SCM as detected by CMT and EC was 27.83 and $19.95 \%$ respectively whereas the animal-wise incidence was 52.28 and $38.13 \%$ for CMT and EC respectively.

\section{Treatment of subclinical mastitis in dairy cow}

Several systematic antibiotics such as procaine penicillin $\mathrm{G}$, amoxicillin, ampicillin and oxytetracycline are effective against mastitis (Preez, 2000). Salat et al. (2008) found that systemic treatment of subclinical mastitis with penethamate is effective. The bacteriological cure (BC) of infected quarters has a sustained positive effect on milk SCC during the treatment. Nutrition and feeding management can affect the outcome of mastitis, and some of these nutritional components are less specific to older cows due to differences in their nutrient requirements and metabolism (Saroj et al., 2015).

The therapeutic use of oil extracts of Ocimum sanctum (tulsi) with Azadirachta indica (neem) and aqueous extract of Tinospora cordifola (giloy) gave good results for reducing bacterial load and enhancement of phagocytic capacity (Dash, 2001). Mastitis remains one of the most economically devastating diseases in dairy cows. Pandey and Kumar (2018) observed that herbal spray was effective against subclinical mastitis in dairy cows. Administration of tylosin along with benethamine penicillin, penethamate hydriodide and framycetin showed effective results in dairy cattle affected with subclinical mastitis (Ismail et al., 2018).

\section{Prevention and control measures}

The outbreak of SCM can be prevented either pre and post milking udder disinfection or by changes in milking technique like using machine milking (Mpatswenumugabo et al., 2017). The contribution of dietary management in the development of mastitis has been controversial and difficult to isolate from other confounding effects. Feeding high-concentrate diets to increase milk yield was a risk factor for mastitis and complexity in udder metabolism (Hamilton et al., 2006) but significant effects of nutrition on udder health which predisposes to mastitis and ketosis in dairy cow (O'Rourke, 2009). Dietary deficiencies of selenium and vitamin $\mathrm{E}$ cause of increasing incidence as well as the duration of mastitis. So, a balanced diet should be provided to dairy animals along with hygienic managemental conditions. Kumari et al. (2018) observed the efficacy of herbal preparations as an internal and external sealant against subclinical mastitis in dairy cow management. They found that TM or R herbal products along with the company as internal teat sealant helps in treating subclinical mastitis in dairy cows. McParland et al. (2019) observed that the use of teat sealant alone could be beneficial in dairy cows with an efficient mastitis control program by decreasing the subclinical mastitis cases.

Dry cow therapy has shown effective results in eliminating the existing intramammary infections and preventing the occurrence of new intramammary infections; hence plays a vital role in the mastitis control programme. This therapy includes administering intra-mammary or systemic antibiotics during the dry period ( 2 weeks before parturition) (Kashif et al., 2016). Leitner et al. (2018) utilized acoustic pulse therapy for treating subclinical mastitis and estimated $70.5 \%$ of mastitis cattle return to 
normal milk yield than the control group $(18.4 \%)$.

National Mastitis Council (NMC, 2000) developed ten steps list to follow in a mastitis control program which includes: establish goals for udder health, maintain a clean, dry, comfortable environment, follow proper milking procedures, maintain and use milking equipment properly, keep good records, manage clinical mastitis during lactation appropriately, establish an effective dry cow management program, follow a biosecurity program against contagious pathogens, monitor udder health status regularly and periodically review your mastitis control program.

\section{Conclusion}

Subclinical mastitis is a major health concern for dairy cows, as it causes silent economic loss without visible alteration in the milk. SCM causes 3-5 times more financial loss

\section{REFERENCES}

Abdeta D and Birhanu G, 2020. A study on the prevalence of subclinical mastitis in lactating cows and associated risk factors in Wolmara district, Oromia Regional State, Ethiopia. Biomed J Sci Tech Res, 28(2): 21421-21426, doi: 10.26717/ BJSTR.2020.28.004621

Abrahmsén M, Persson Y, Kanyima BM and Båge R, 2014. Prevalence of subclinical mastitis in dairy farms in urban and peri-urban areas of Kampala, Uganda. Trop Anim Health Prod, 46: 99-105, doi: 10.1007/s11250-013-0455-7

Balaji SN and Senthilkumar A, 2017. Prevalence of subclinical mastitis in dairy cows of Theni district in Tamil Nadu. Int J Sci Environ Tech, 6(6): 3427 3432

Banerjee S, Batabyal K, Joardar SN, Isore DP, Dey S et al., 2017. Detection and characterization of pathogenic Pseudomonas aeruginosa from bovine subclinical mastitis in West Bengal, India. Vet World, 10(7): 738-742, doi: 10.14202/ vetworld.2017.738-742

Bangar YC, Singh B, Dohare AK and Verma MR, 2015. A systematic review and meta-analysis of prevalence of subclinical mastitis in dairy cows in India. Trop Anim Health Prod, 47(2): 291-297, doi: $10.1007 / \mathrm{s} 11250-014-0718-y$ than clinical mastitis. SCM prevalence is also highly associated with the agroclimatic condition affecting milk production in dairy cattle. The following prevention strategies should be followed to overcome SCM, such as implementing good management in a dairy farm, regular checkup of animals for early diagnosis and proper treatment, which may reduce health-related problems and occurrence of concurrent diseases in dairy cows. The hygienic practice of milking has a more significant impact on lowering SCM incidence, which includes dry cow therapy, post milking teat disinfection, and the use of sterile gloves while milking. So, by following the above steps, we can prevent SCM and minimize economic losses by improving the quality and quantity of milk.

Conflict of interest: Authors have no conflict of interest in this study.

Barkema HW, Schukken YH and Zadoks RN, 2006. The role of cow, pathogen, and treatment regimen in the therapeutic success of bovine Staphylococcus aureus mastitis. J Dairy Sci, 89(6): 1877-1895, doi: $10.3168 /$ jds. S00220302(06)72256-1

Barkema HW, Vliegher SD, Piepers S and Zadoks RN, 2013. Herd level approach to high bulk milk somatic cell count problems in dairy cattle. Vet Quarterly, 33(2): 82-89, doi: 10.1080/ 01652176.2013 .799791

Bertocchi L, Vitali A, Lacetera N, Nardone A, Varisco G et al., 2014. Seasonal variations in the composition of Holstein cow's milk and temperature-humidity index relationship. Animal, 8(4): 667-674, doi: $10.1017 / \mathrm{S} 1751731114000032$

Bohmanova J, Misztal I and Cole JB, 2007. Temperature-humidity indices as indicators of milk production losses due to heat stress. J Dairy Sci, 90(4): 1947-1956, doi: 10.3168/jds.2006-513

Bouraoui R, Lahmar M, Majdoub A, Djemali M and Belyea R, 2002. The relationship of temperaturehumidity index with milk production of dairy cows in a Mediterranean climate. Anim Res, 51(6): 479491, doi: 10.1051/animres:2002036

Bronzo V, Lopreiato V, Riva F, Amadori M, Curone G 
et al., 2020. The role of innate immune response and microbiome in resilience of dairy cattle to disease: the mastitis model. Animals, 10(8): 1397, doi: 10.3390/ani10081397

Busato A, Trachsel P, Schallibaum M and Blum JW, 2000. Udder health and risk factors for subclinical mastitis in organic dairy farms in Switzerland. Prev Vet Med, 44(3-4): 205-220, doi: 10.1016/S01675877(00)00104-5

Cheng WN and Han SG, 2020. Bovine mastitis: risk factors, therapeutic strategies, and alternative treatments- A review. Asian-Australas J Anim Sci, 33(11): 1699-1713, doi: 10.5713/ajas.20.0156

Cynthia MK, 2005. The Merck Veterinary Manual, Merck and CO, Inc: Whitehouse Station, NJ

Dash PK, 2001. Immunomodulatory therapy- A new approach in the management of sub-clinical mastitis. Indian Vet Congress, 2: 87-91

De Vliegher S, Fox LK, Piepers S, McDougall S and Barkema HW, 2012. Invited review: mastitis in dairy heifers: nature of the disease, potential impact, prevention, and control. J Dairy Sci, 95(3): 1025-1040, doi: 10.3168/jds.2010-4074

Devi M and Dutta JB, 2018. Incidence of bovine subclinical mastitis in organized and unorganized farms based on somatic cell count. Int J Chem Stud, 6(4): 1399-1403

Dey D, Sharma B and Mondal S, 2019. Nutritional approach to prevent mastitis of dairy cattle. Environ Ecol, 37(1B): 344-348

Dikmen S and Hansen PJ, 2009. Is the temperaturehumidity index the best indicator of heat stress in lactating dairy cows in a subtropical environment? J Dairy Sci, 92(1): 109-116, doi: 10.3168/ jds.2008-1370

Durr JW, Cue RI, Monardes HG, Moro-Méndez J and Wade KM, 2008. Milk losses associated with somatic cell counts per breed, parity and stage of lactation in Canadian dairy cattle. Livest Sci, 117(2-3): 225- 232, doi: 10.1016/ j.livsci.2007.12.004

Fahim KM, Ismael E, Khalefa HS, Farag HS and Hamza DA, 2019. Isolation and characterization of E. coli strains causing intramammary infections from dairy animals and wild birds. Int J Vet Sci Med, 7(1): 61-70, doi: 10.1080/23144599. 2019.1691378

Ghose B and Sharda R, 2003. Bovine mastitis due to Micrococcaceae: isolation and antibiogram. Proceedings of the $4^{\text {th }}$ Round Table Conference on Mastitis, Palampur, HP, India, pp 171- 174

Halasa T, Nielen M, De Roos APW, Van Hoorne R, de
Jong G et al., 2009. Production loss due to new subclinical mastitis in Dutch dairy cows estimated with a test-day model. J Dairy Sci, 92(2): 599606, doi: $10.3168 /$ jds.2008-1564

Hamilton C, Emanuelson U, Forslund K, Hansson I and Ekman T, 2006. Mastitis and related management factors in certified organic dairy herds in Sweden. Acta Vet Scand, 48(1): 1-7, doi: 10.1186/1751-0147-48-11

Hammami H, Bormann J, M'Hamdi N, Montaldo HH and Gengler N, 2013. Evaluation of heat stress effects on production traits and somatic cell score of Holsteins in a temperate environment. J Dairy Sci, 96(3): 1844-1855, doi: 10.3168/jds.20125947

Hande G, Arzu F, Nilgün G, SerhanSerhat AY, Alper C et al., 2015. Investigation on the etiology of subclinical mastitis in Jersey and hybrid Jersey dairy cows. ActaVeterinaria-Beograd, 65 (3): 358370, doi: 10.1515/acve-2015-0030

Haq Z, Khan N, Rastogi A, Sharma RK, Amrutkar S et al., 2016. Nutrition and metabolic diseases in dairy cattle- A review. Int J Agri Sci, 8(12): 1154-1159

Iraguha B, Hamudikuwanda H and Mushonga B, 2015. Bovine mastitis prevalence and associated risk factors in dairy cows in Nyagatare District, Rwanda. J South Afr Vet Assoc, 86(1): 1228, doi: 10.4102/ jsava.v86i1.1228,

Ismail ZB, Muhaffel MM and Abu-Basha E, 2018. The effect of dry cow therapy using systemic tylosin in combination with common intramammary medications on mastitis rate, cull rate, somatic cell count, and milk production in dairy cows affected with subclinical mastitis. Vet World, 11(9): 12661271, doi: 10.14202/vetworld.2018.1266-1271

Jingar SC, Mehla RK and Singh M, 2014. Climatic effects on occurrence of clinical mastitis in different breeds of cows and buffaloes. Arch Zootec, 63(243): 473-482, doi: 10.4321/S000405922014000300008

Joshi S and Gokhale S, 2006. Status of mastitis as an emerging disease in improved and periurban dairy farms in India. Ann New York Acad Sci, 1081: 7483, doi: 10.1196/annals.1373.007

Kader MA, Samad MA, Saha S and Taleb MA, 2002. Prevalence and etiology of sub clinical mastitis with antibiotic sensitivity to isolated organisms among milch cows in Bangladesh. Indian J Dairy Sci, 55: 218-223

Karabasanavar NS, Radder SK and Sivaraman GK, 2019. Field level interventions on subclinical mastitis and detection of Staphylococcus in crossbred 


\section{An overview of subclinical mastitis in dairy cattle}

dairy cows. Indian J Anim Sci, 89(7): 711-717

Kashif M, Rizwan M, Ali M, Ahmad T and Durrani AZ, 2016. Control of mastitis through dry cow therapy: A review. Veterinaria, 4(2): 13-16

Keefe G, 2012. Update on control of Staphylococcus aureus and Streptococcus agalactiae for management of mastitis. Vet Clin North Am Food Anim Pract, 28: 203-216, doi: 10.1016/ j.cvfa.2012.03.010

Khate K and Yadav BR, 2010. Incidence of mastitis in Sahiwal cattle and Murrah buffaloes of a closed organized herd. Indian J Anim Sci, 80(5): 467469

Kumari T, Bhakat C and Choudhary RK, 2018. Use of herbal preparations in dry cow management against sub clinical mastitis-An alternative approach. Int J Livest Res, 9(3): 21-27, doi: 10.5455/ijlr.20180215053754

Langer A, Sharma S, Sharma NK and Nauriyal DS, 2014. Comparative efficacy of different mastitis markers for diagnosis of sub-clinical mastitis in cows. Int J Appl Sci Biotechnol, 2(2): 121-125, doi: 10.3126/ijasbt.v2i2.10191

Leitner G, Zilberman D, Papirov E and Shefy S, 2018. Assessment of acoustic pulse therapy (APT), a nonantibiotic treatment for dairy cows with clinical and subclinical mastitis. PLoS One, 13(7): e0199195, doi: 10.1371/journal.pone.0199195

Mbindyo CM, Gitao GC and Mulei CM, 2020. Prevalence, etiology, and risk factors of mastitis in dairy cattle in Embu and Kajiado Counties, Kenya.Vet Med Int: ID-8831172, doi: 10.1155/ 2020/8831172

McParland S, Dillon PG, Flynn J, Ryan N, Arkins S et al., 2019. Effect of using internal teat sealant with or without antibiotic therapy at dry-off on subsequent somatic cell count and milk production. J Dairy Sci, 102(5): 4464-4475, doi: 10.3168/jds.2018-15195

Mollalegn B, Arega T and Tadele T, 2010. Study on bovine mastitis in dairy farms of Bahirdar and its environs. J Anim Vet Adv, 9(23): 2912-2917, doi: 10.3923/javaa.2010.2912.2917

Mpatswenumugabo JP, Bebora LC, Gitao GC, Mobegi VA, Iraguha B et al., 2017. Prevalence of subclinical mastitis and distribution of pathogens in dairy farms of Rubavu and Nyabihu districts, Rwanda. J Vet Med: ID-8456713, doi: 10.1155/ 2017/8456713

Ndahetuye JB, Persson Y, Nyman AK, Tukei M, Ongol MP et al., 2019. Aetiology and prevalence of subclinical mastitis in dairy herds in peri-urban areas of Kigali in Rwanda. Trop Anim Health Prod, 51(7): 2037-2044, doi: 10.1007/s 11250-01901905-2

NMC, 2000. National Mastitis Council: Recommended Mastitis Control Program, https:// manitowoc.extension.wisc.edu/files/2011/10/ NMC-Mastitis-Control-Program1.pdf

Nonnemann B, Lyhs U, Svennesen L, Kristensen K, Klaas I et al., 2019. Bovine mastitis bacteria resolved by MALDI-TOF mass spectrometry. J Dairy Sci, 102(3): 2515- 2524, doi: 10.3168/ jds.2018-15424

O'Rourke D, 2009. Nutrition and udder health in dairy cows: A review. Irish Vet J, 62(S15): 1-6, doi: 10.1186/2046-0481-62-S4-S15

Pandey AK and Kumar P, 2018. Efficacy herbal spray in treating subclinical mastitis in cattle. Int Dairy Topics, 17(6): 15-16

Pankaj, Sharma A, Chhabra R and Sindhu N, 2012. Prevalence of sub clinical mastitis in cows: its etiology and antibiogram. Indian J Anim Res, 46(4): 348-353

Pereira UP, Oliveira DGS, Mesquita LR, Costa GM and Pereira LJ, 2011. Efficacy of Staphylococcus aureus vaccines for bovine mastitis: A systematic review. Vet Microbiol, 148: 117-124, doi: 10.1016/j.vetmic.2010.10.003

Pérez MM, Prenafeta A, Valle J, Penadés J, Rota C et al., 2009. Protection from Staphylococcus aureus mastitis associated with poly-N-acetyl $\beta$ 1,6 glucosamine specific antibody production using biofilm-embedded bacteria. Vaccine, 27: 2379-2386, doi: 10.1016/j.vaccine.2009.02.005

Persson W, Bengtsson K, Lindberg B, Nyman A and Ericsson U, 2009. Incidence of mastitis and bacterial findings at clinical mastitis in Swedish primiparous cows - influence of breed and stage of lactation. Vet Microbiol, 134: 89-94, doi: 10.1016/j.vetmic.2008.09.004.

Preez Du JH, 2000. Bovine mastitis therapy and why it fails: continuing education. J S African Vet Assoc, 71(3): 201-208

Radostits OM, Gay CC, Hinchcliff KW and Constable PD, 2007. Veterinary Medicine- A Textbook of the Diseases of Cattle, Sheep, Pigs, Goats and Horses, $10^{\text {th }}$ edn., Saunders Elsevier, Spain, pp 1045-1046

Rathod P, Shivamurty V and Desai AR, 2017. Economic losses due to subclinical mastitis in dairy animals: A study in Bidar district of Karnataka. Indian J Vet Sci Biotech, 13(1): 37-41, doi: 10.21887/ijvsbt.v13i01.8732

Reddy BSS, Shobhamani B, Sreedevi B, Nalini 
Kumari K and Reddy YR, 2015. Diagnosis of subclinical mastitis in cross bred cattle. J Vet Sci Technol, 4(3): 39-43, doi: 10.37591/ rrjovst.v4i3.574

Rodriguez SL, Gianola D and Shookg E, 2000. Evaluation of models for somatic cell score lactation patterns in Holsteins. Livest Product Sci, 67(1-2): 19-30, doi: 10.1016/S0301-6226(00) 00193-7

Ruegg P, 2017. A 100-year review: mastitis detection, management, and prevention. J Dairy Sci, 100(12): 10381-10397, doi: 10.3168/jds.2017-13023

Sahoo P, Sahoo N and Biswal S, 2020. Etiology and antibiogram of subclinical mastitis in cows of Puri district, India. Int J Curr Microbiol App Sci, 9(7): 374-379, doi: 10.20546/ijcmas.2020.907.040

Salat O, Sérieys F, Poutrel B, Durel L and Goby L, 2008. Systemic treatment of subclinical mastitis in lactating cows with penethamatehydriodide. J Dairy Sci, 91(2): 632-40, doi: 10.3168/jds.2007-0174

Saroj S, Ganguly S and Mahajan T, 2015. Applied nutritional management of clinical mastitis in dairy cattle: A review. Int J Sci Environ Technol, 4(5): 1351-1359.

Senthilkumar S, Murugesan and Balamurugan P, 2020. Prevalence and detection of subclinical mastitis by California Mastitis Test (CMT) in dairy farms of Theni district in Tamil Nadu, India. Int J Curr Microbiol App Sci, 9(7): 988-993, doi: 10.20546/ ijcmas.2020.907.116

Sharma N, Maiti SK and Pandey V, 2008. Sensitivity of indirect tests in the detection of subclinical mastitis in buffaloes. Vet Practitioner, 9(1): 29-31

Sinha MK, Thombare NN and Mondal B, 2014. Subclinical mastitis in dairy animals: incidence, economics, and predisposing factors. Sci World J, 2014: ID-523984, doi: 10.1155/2014/523984

Sudhan NA and Sharma N, 2010. Mastitis- An important production disease of dairy animals, SMVS' (Serva Manav Vikas Samiti) Dairy Year Book, pp 72-78

Sumon S, Ehsan M and Islam M, 2017. Subclinical mastitis in dairy cows: somatic cell counts and associated bacteria in Mymensingh, Bangladesh. J Bangladesh Agril Univ, 15(2): 266-271, doi: 10.3329/jbau.v15i2.35073

Susanty H, Purwanto BP, Sudarwanto M and Atabany A, 2018. Agroclimatic effects on milk production and sub-clinical mastitis prevalence in dairy cattle. J Indonesian Trop Anim Agri, 43(4): 373-382, doi: 10.14710/jitaa.43.4.373-382

Tresamol PV, Ratheesh RL, Aron J and Saseendranath MR, 2019. Comparison of two cow side tests for diagnosis of subclinical mastitis in cows. Pharma Innov J, 8(8): 29-31

Varshney JP and Naresh R, 2004. Evaluation of a homeopathic complex in the clinical management of udder diseases of riverine buffaloes. Homeopathy, 93(1): 17-20, doi: 10.1016/ j.homp.2003.11.007

Yadav R, Kumar P and Sandeep, 2019. Prevalence of bovine subclinical mastitis in Mahendergarh and Rewari districts of south Haryana. Haryana Vet, 58(1): $97-100$ 